\title{
Acute generalized exanthematous pustulosis caused by a probable spider bite: A case report and review of the literature
}

Muhtemelen örümcek ısırığı sonrası gelișen akut jeneralize ekzantematöz püstüloz: Olgu sunumu ve literatürün gözden geçirilmesi

\section{Fatmagül Dirican, ๑ Ayda Acar, ๑ Banu Yaman*, ๑ Bengü Gerçeker Türk}

Ege University Faculty of Medicine, Department of Dermatology; *Department of Pathology, İzmir, Turkey

\begin{abstract}
Acute generalized exanthematous pustulosis (AGEP) is a toxic cutaneous reaction pattern that is mostly caused by drug intake and rarely associated with spider bites. We report a case of a female patient, 47 years old, with febrile pustular lesions on an erythematous base at the abdominal region. She had three violaceous erythematous and edematous plaques on the interscapular region, one of which had a necrotic crust at its center. The lesions were compatible with spider bites. By considering histopathological and clinical findings, the patient was diagnosed with AGEP. Since she had no history of drug intake, viral infection or other triggers, a spider bite was thought to have caused the AGEP.

Keywords: Acute generalized exanthematous pustulosis, spider bite, sterile pustules

Öz

Akut jeneralize ekzantematöz püstüloz (AGEP), çoğunlukla ilaç kullanımı ile tetiklenen ve nadiren örümcek ısırı̆ııla ilişkili olan toksik bir deri reaksiyonudur. Burada, kliniğimize karın bölgesinde eritemli zeminde febril, püstüler lezyon gelişimi nedeniyle başvuran 47 yaşında bir kadın olgu sunulmaktadır. Olgunun dermatolojik muayenesinde; interskapular bölgede bir tanesinin ortasında nekrotik krutu bulunan üç adet sıralı viyolese eritemli, ödemli plaklar izlendi. Bu lezyonlar örümcek ııırı̆ıı ile uyumluydu. Histopatolojik ve klinik bulgulara dayanarak hastaya AGEP tanısı konuldu. ilaç kullanımı, viral enfeksiyon veya başka bir tetikleyici öyküsü olmadığı için AGEP lezyonlarının örümcek ısırığından kaynaklandığı düşünüldü. Bu olgu, AGEP’nin nedenleri arasında örümcek ısııı̆ının daha ciddiyetle düşünülmesi gerektiğini göstermesi açısından önem taşımaktadır.
\end{abstract}

Anahtar Kelimeler: Akut jeneralize ekzantematöz püstüloz, örümcek ısırı̆ı, steril püstül

\section{Introduction}

Acute generalized exanthematous pustulosis (AGEP) is a febrile skin reaction which is characterized by the small nonfollicular sterile pustules on an erythematous base ${ }^{1}$. Ninety percent of cases are caused by drugs such as pristinamycin, aminopenicillins, quinolone, sulfonamides, antimalarials, terbinafine, calcium channel blockers, corticosteroids, allopurinol and antiepileptics ${ }^{2}$. Viral infections, ingestion of lacquered chicken, chromium picolinate, mercury and spider bites have rarely been associated with AGEP2-5,6-13, as in this reported case.

\section{Case Report}

A 47-year-old female patient sought medical attention due to febrile pustular lesions on an erythematous base on her

Address for Correspondence/Yazışma Adresi: Fatmagül Dirican MD, Ege University Faculty of Medicine, Department of Dermatology, İmir, Turkey Phone: +90 5548798364 E-mail: fgdirican@hotmail.com Received/Geliş Tarihi: 11.01.2020 Accepted/Kabul Tarihi: 18.05.2020 ORCID: orcid.org/0000-0002-3992-6738 
Table 1. Some features of case reports reporting the development of AGEP after spider bite

\begin{tabular}{|c|c|c|c|c|c|c|c|}
\hline Literature & $\begin{array}{l}\text { Sex, } \\
\text { age }\end{array}$ & Clinical and laboratory features & $\begin{array}{l}\text { Time to } \\
\text { onset }\end{array}$ & Co-medication & $\begin{array}{l}\text { Medical } \\
\text { history }\end{array}$ & Histopathology & Treatment \\
\hline $\begin{array}{l}\text { Davidovici } \\
\text { et al. }{ }^{6} \\
1^{\text {st }} \text { case }\end{array}$ & F, 37 & $\begin{array}{l}\text { Necrotic crusts (two), erythema, } \\
\text { edema, non-follicular and follicular, } \\
\text { sterile pustules mainly on the folds } \\
\text { neutrophils: } 10,100 / \mu \mathrm{L} \text {, eozinophils: } \\
18.9 \% \text {, viral serology negative }\end{array}$ & $48 \mathrm{~h}$ & $\begin{array}{l}\text { Amoxicillin } \\
\text { with } \\
\text { clavulanate }\end{array}$ & Unremarkable & $\begin{array}{l}\text { Subcorneal pustule } \\
\text { associated with spongiosis } \\
\text { of epidermis. Mild edema } \\
\text { in upper dermis }\end{array}$ & NK \\
\hline $\begin{array}{l}\text { Davidovici } \\
\text { et al. }{ }^{6} \\
2^{\text {nd }} \text { case }\end{array}$ & F, 41 & $\begin{array}{l}\text { Necrotic crust, erythema, edema, pain, } \\
\text { non-follicular, sterile pustules on trunk } \\
\text { and limbs, high fever }\left(38.8^{\circ} \mathrm{C}\right) \\
\text { neutrophils: } 9,630 / \mu \mathrm{L} \text {, eosinophils: } \\
5.7 \% \text {, viral serology negative }\end{array}$ & $24 \mathrm{~h}$ & No & $\begin{array}{l}\text { Juvenile } \\
\text { periodontitis }\end{array}$ & $\begin{array}{l}\text { Subcorneal/intraepidermal } \\
\text { pustule filled with } \\
\text { neutrophils, spongiosis and } \\
\text { acanthosis. Mild edema } \\
\text { and mixed perivascular } \\
\text { infiltrate with a few } \\
\text { eosinophils in upper dermis }\end{array}$ & NK \\
\hline $\begin{array}{l}\text { Davidovici } \\
\text { et al. }{ }^{6} \\
3^{\text {rd }} \text { case }\end{array}$ & $M, 44$ & $\begin{array}{l}\text { Necrotic crust, vesicles, erythema, } \\
\text { edema, pruritus, vomiting, Coomb's } \\
\text { positive hemolytic anemia, malaise, } \\
\text { non-follicular and follicular, sterile } \\
\text { pustules mainly on the folds, high } \\
\text { fever }\left(38.4^{\circ} \mathrm{C}\right) \text {, neutrophils: } 8,450 / \\
\mu \mathrm{L} \text {, eosinophils: } 11 \% \text {, viral serology } \\
\text { negative }\end{array}$ & $24 \mathrm{~h}$ & No & $\begin{array}{l}\text { Thalassemia } \\
\text { minor }\end{array}$ & $\begin{array}{l}\text { Subcorneal pustule and } \\
\text { folliculitis. Mild edema in } \\
\text { papillary dermis. Moderate } \\
\text { superficial and deep } \\
\text { infiltrates in dermis. }\end{array}$ & NK \\
\hline $\begin{array}{l}\text { Makris et } \\
\text { al. }\end{array}$ & F, 56 & $\begin{array}{l}\text { Dermonecrotic skin lesions with } \\
\text { erythema and edema on left popliteal } \\
\text { fossa, small, pinhead sized, non- } \\
\text { follicular pustules mainly on the folds, } \\
\text { high fever }\left(38-39^{\circ} \mathrm{C}\right) \\
\text { Leukocyte: } 18,300 / \mu \mathrm{L}, \\
\text { neutrophils: } 11,970 / \mu \mathrm{L}, \text { eosinophils: } \\
650 / \mu \mathrm{L}, \mathrm{CRP}: 17.1 \mathrm{mg} / \mu \mathrm{L}, \text { blood and } \\
\text { pustules culture are negative, viral } \\
\text { serology negative }\end{array}$ & $72 \mathrm{~h}$ & $\begin{array}{l}\text { Clindamycin } \\
\text { and } \\
\text { cefuroxime }\end{array}$ & NK & $\begin{array}{l}\text { Subcorneal and } \\
\text { intraepidermal pustules, } \\
\text { edema of the papillary } \\
\text { dermis and diffuse } \\
\text { perivascular infiltration } \\
\text { of neutrophils and a few } \\
\text { eosinophils }\end{array}$ & NK \\
\hline $\begin{array}{l}\text { Ermertcan } \\
\text { et al. }{ }^{8}\end{array}$ & F, 39 & $\begin{array}{l}\text { Indurated necrotic plaque on the left } \\
\text { forearm, diffuse erythema on the body } \\
\text { and small pustules over erythematous } \\
\text { skin, especially located on the left } \\
\text { popliteal fossa and gluteal region. } \\
\text { Leukocytosis, neutrophilia }\end{array}$ & $24 \mathrm{~h}$ & No & NK & $\begin{array}{l}\text { Subcorneal and } \\
\text { intraepidermal pustules, } \\
\text { edema of the papillary } \\
\text { dermis, and diffuse } \\
\text { perivascular inflammatory } \\
\text { infiltration }\end{array}$ & $\begin{array}{l}\text { Systemic antibiotic } \\
\text { therapy, topical } \\
\text { antiseptic agents, wet } \\
\text { dressing }\end{array}$ \\
\hline Lane et al. ${ }^{9}$ & $M, 9$ & $\begin{array}{l}\text { Thousands of disseminated pustules } \\
\text { mainly in the skin folds, pain, swelling, } \\
\text { fever }\left(38.6^{\circ} \mathrm{C}\right) \text {, Coomb's positive } \\
\text { hemolytic anemia, neutrophils: } 11,040 / \\
\text { ML, leukocyte: } 16,000 / \mu \mathrm{L} \text {, hemoglobin: } \\
11 \mathrm{~g} / \mathrm{dL}, \mathrm{AST}: 61 \mathrm{U} / \mathrm{L} \text {, ALT: } 65 \mathrm{U} / \mathrm{L}\end{array}$ & $24-72 \mathrm{~h}$ & No & NK & NK & NK \\
\hline $\begin{array}{l}\text { de Mattos } \\
\text { Milman et } \\
\text { al. }^{10}\end{array}$ & $M, 48$ & $\begin{array}{l}\text { Erythematous eruption accompained } \\
\text { by several disseminated small non } \\
\text { follicular pustules, pruritus, high fever } \\
\left(38^{\circ} \mathrm{C}\right) \text {, } \\
\text { leukocytosis: } 27,260 / \mu \mathrm{L} \text { (predominance } \\
\text { of neutrophils), ALT: } 268 \mathrm{U} / \mathrm{L} \text {, AST: } 56 \\
\mathrm{U} / \mathrm{L} \text {, GGT: } 366 \mathrm{U} / \mathrm{L} \text {, total bilirubin: } 2.5 \\
\mathrm{mg} / \mathrm{dL} \text {, hepatitis viral serology negative }\end{array}$ & $36 \mathrm{~h}$ & No & NK & $\begin{array}{l}\text { Pustular dermatitis with } \\
\text { neutrophilic vasculitis, } \\
\text { focally purpuric, discrete } \\
\text { edema in the dermal } \\
\text { papillae and absence of } \\
\text { leukocytoclasia }\end{array}$ & $\begin{array}{l}\text { Prednisone } 80 \mathrm{mg} / \\
\text { day }\end{array}$ \\
\hline $\begin{array}{l}\text { Bhat et al. }{ }^{11} \\
1^{\text {st }} \text { case }\end{array}$ & $\mathrm{F}$ & $\begin{array}{l}\text { Non-follicular, sterile pustules. } \\
\text { erythematous, edematous, ulcerated, } \\
\text { necrotic skin lesion on the neck, } \\
\text { high fever, negative gram staining of } \\
\text { pustules, neutrophilia }\end{array}$ & $24 \mathrm{~h}$ & $\begin{array}{l}\text { Amoxicillin- } \\
\text { calvulinic asit }\end{array}$ & NK & $\begin{array}{l}\text { Subcorneal pustule with } \\
\text { mild edema }\end{array}$ & Symptomatic \\
\hline $\begin{array}{l}\text { Bhat et al. }{ }^{11} \\
2^{\text {nd }} \text { case }\end{array}$ & $\mathrm{F}$ & $\begin{array}{l}\text { Non-follicular sterile pustules, } \\
\text { erythematous, edematous, necrotic } \\
\text { skin lesion on the lower back, } \\
\text { negative gram staining of pustules, } \\
\text { eosinophilia, neutrophilia }\end{array}$ & $24 \mathrm{~h}$ & No & NK & $\begin{array}{l}\text { Subcorneal pustule with } \\
\text { papillary dermal edema } \\
\text { and perivascular infiltrate } \\
\text { in upper dermis }\end{array}$ & Symptomatic \\
\hline
\end{tabular}




\begin{tabular}{|c|c|c|c|c|c|c|c|}
\hline $\begin{array}{l}\text { Bhat et al. }{ }^{11} \\
3^{\text {th }} \text { case }\end{array}$ & M & $\begin{array}{l}\text { Non-follicular sterile pustules, } \\
\text { erythematous, ulcerated, necrotic skin } \\
\text { lesion on the right shoulder, high fever, } \\
\text { negative gram staining of pustules, } \\
\text { neutrophilia }\end{array}$ & $72 \mathrm{~h}$ & No & NK & $\begin{array}{l}\text { Subcorneal pustule with } \\
\text { papillary dermal edema } \\
\text { and perivascular infiltrate } \\
\text { in dermis }\end{array}$ & Symptomatic \\
\hline $\begin{array}{l}\text { Pippirs et } \\
\text { al. }{ }^{12}\end{array}$ & F, 54 & $\begin{array}{l}\text { A dermonecrotic lesion on the left side } \\
\text { of her abdomen, } \\
\text { hundreds of pinhead-sized, non- } \\
\text { follicular, sterile pustules on the trunk } \\
\text { and limbs, lymphadenopathy in the left } \\
\text { axillary region, mild fever, } \\
\text { increase of CRP }\left(4.1 \mathrm{mg} / \mathrm{dL}^{-1}\right) \text {, normal } \\
\text { pattern of leukocytes }\end{array}$ & $48 \mathrm{~h}$ & NK & NK & $\begin{array}{l}\text { Subcorneal and } \\
\text { intraepidermal pustule } \\
\text { with partly perivascular } \\
\text { and partly interstitial } \\
\text { inflammatory infiltrate. }\end{array}$ & $\begin{array}{l}\text { Local wound care, } \\
\text { prophylaxis with } \\
\text { systemic antibiotic, } \\
\text { antipruritic therapy }\end{array}$ \\
\hline $\begin{array}{l}\text { The } \\
\text { presented } \\
\text { case }\end{array}$ & $F, 47$ & $\begin{array}{l}3 \text { violaceous erythematous, edematous } \\
\text { plaques in the interscapular region, one } \\
\text { of which had a necrotic crust in the } \\
\text { middle of pinhead sized, non-follicular } \\
\text { pustules and vesicles especially located } \\
\text { flexural areas. } \\
\text { Leukocyte: } 9,890 / \mu \mathrm{L}, \text { neutrophils: } \\
8,330 / \mu \mathrm{L}, \mathrm{CRP}: 19.51 \mathrm{mg} / \mathrm{dL} \text {, anti- } \\
\text { HCV positive, HCV viral load negative, } \\
\text { bacterial swab culture negative }\end{array}$ & $24 \mathrm{~h}$ & No & $\begin{array}{l}\text { Chronic } \\
\text { kidney failure, } \\
\text { depression } \\
\text { and previous } \\
\text { hepatitis c } \\
\text { infection }\end{array}$ & $\begin{array}{l}\text { Intraepidermal } \\
\text { polymorphonuclear } \\
\text { leukocytes and eosinophil- } \\
\text { rich pustule formations, } \\
\text { edema of the papillary } \\
\text { dermis and diffuse } \\
\text { perivascular inflammatory } \\
\text { infiltration }\end{array}$ & $\begin{array}{l}80 \mathrm{mg} \\
\text { methylprednisolone, } \\
\text { wet dressing, } \\
\text { antihistamines }\end{array}$ \\
\hline
\end{tabular}

abdominal region. She reported that she had visited a vineyard and seen spiders there. She had a red and itchy rash on her back during her visit. After 24 hours, the patient presented numerous pinhead sized inflammatory acne-like lesions on an erythematous macule on her abdominal region, and had a fever of $39^{\circ} \mathrm{C}$. She had not taken any drug preceding the eruption. Additionally, the patient's medical history included chronic kidney failure, hepatitis C infection, depression but her family history was non-significant.

On dermatological examination, it was observed that there were three violaceous, erythematous and edematous plaques on the interscapular region, one of which had a necrotic crust at its center (Figure 1a).

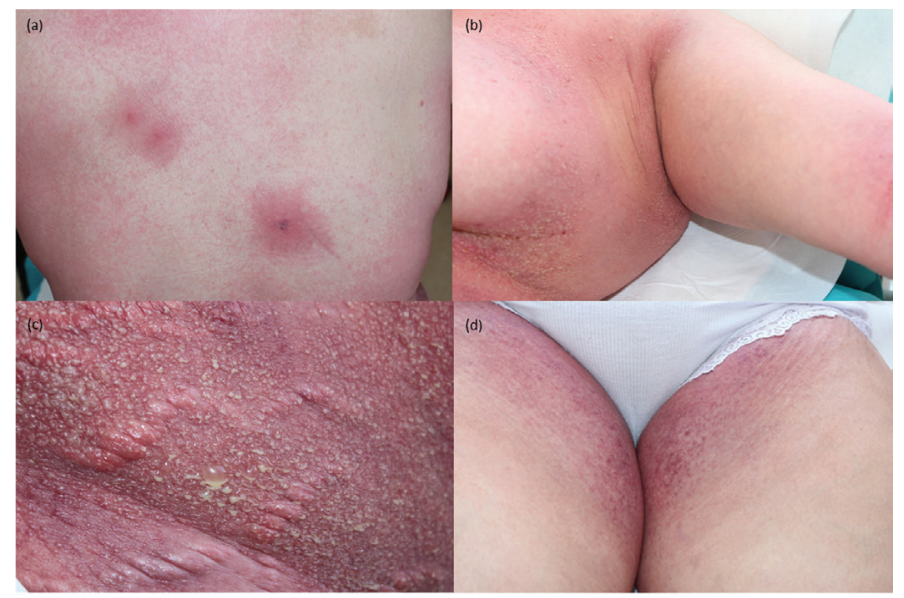

Figure 1. Posterior trunk; a centrally necrotic crusted lesion (on the right), two edematous and erythematous plaques appear like that of an insect bite (on the left) (a). Pinhead sized, non-follicular pustules on an erythematous base on the axillary and below the mammary area (b), abdominal region (c) and on the both inguinal folds (d)
Moreover, the patient had pinhead sized non-follicular pustules and vesicles on a violaceous erythematous base on the axillary, abdominal and inguinal region, especially located on the flexural areas (Figure $1 b, c, d)$. Bacterial culture from the pustule was negative. Laboratory tests were remarkable for neutrophilia $\left(8,310 / \mathrm{mm}^{3}\right)$, C-reactive protein (CRP) elevation (19.51 mg/dL) and moderate eosinophilia $\left(520 / \mathrm{mm}^{3}\right)$. In viral serology, anti-hepatit C virus (anti-HCV) antibody was positive but HCV viral load was negative. Histopathological examination revealed intraepidermal polymorphonuclear leukocytes and eosinophilrich pustule formations, edema of the papillary dermis and diffuse perivascular inflammatory infiltration (Figure 2). These findings were compatible with AGEP.

Methylprednisolone $80 \mathrm{mg} /$ day was administered parenterally to the patient by a gradual dose reduction plan. The steroid was discontinued after one month with a decrease of $8 \mathrm{mg}$ in each per 3 days. A wet dressing and topical steroid were applied. With this treatment regimen, lesions rapidly resolved. No recurrence was observed in follow-up on the $3^{\text {rd }}, 6^{\text {th }}$, and $12^{\text {th }}$ months after steroid cessation.

Informed consent was obtained.

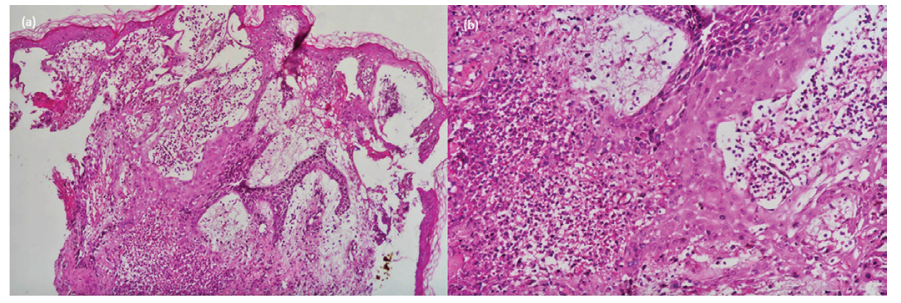

Figure 2. Intraepidermal pustule formation and dermal dense mixed inflammatory cell infiltrates including eosinophils and polymorphonuclear leucocytes (hematoxylin and eosin, x40, 200) 


\section{Discussion}

In medication-related cases, the latency between the drug intake and the appearance of an eruption is less than 4 days ${ }^{14}$. This period has been reported to vary between 1 and 3 days in cases with AGEP caused by a spider bite. According to the drug-related events, it is noteworthy that the latent period is shorter in the cases of AGEP due to a spider bite. Clinically, AGEP is characterized by diffuse non-follicular sterile pustules on an erythematous-edematous base, facial edema, high fever and leukocytosis, neutrophilia, and eosinophilia in peripheral blood count. The trunk and the flexures are areas that are frequently involved in AGEP, as in our patient ${ }^{14}$. The mechanism of the development of AGEP caused by a spider bite is not completely known, but it has been hypothesized that it may be caused by the cytokines released by the spider venom ${ }^{7}$. Fourteen cases of AGEP triggered by spider bite were reported in the literature and they are summarized in Table 1.

The development of AGEP due to spider bites have been seen in adults aged 37 to 56 years, except a 9-year-old child. Dermatological examination of all cases includes non-follicular, pinhead sized, sterile pustules with dermonecrotic skin lesions due to a spider bite. In all cases, except for the case reported by Pippirs et al. ${ }^{12}$, neutrophil dominance was seen in the blood count. The occurrence of pustules is seen between 24 and 72 hours after the spider bite. Approximately half of the cases occurred within the first 24 hours. Since there were antibiotic usages in three of them, the development of AGEP can not be explained only by spider venom in these reported cases. Histopathological examination revealed subcorneal/intraepidermal pustule formations in all cases.

Symptoms were controlled by systemic corticosteroid therapy, and also symptomatic treatment was effective in controlling them.

The presented case is important in showing that non-drug-triggered factors, such as spider bites, can be considered as a serious cause of AGEP.

Ethics

Informed Consent: It was obtained.

Peer-review: Externally peer-reviewed.

\section{Authorship Contributions}

Surgical and Medical Practices: F.D., A.A., B.Y., B.G.T., Concept: F.D., A.A.,
B.G.T., Design: F.D., B.G.T., Data Collection or Processing: F.D., Analysis or Interpretation: F.D., Literature Search: F.D., Writing: F.D., A.A., B.Y., B.G.T. Conflict of Interest: No conflict of interest was declared by the authors.

Financial Disclosure: The authors declared that this study has received no financial support.

\section{References}

1. Sidoroff A, Halevy S, Bavinck JN, et al: Acute generalized exanthematous pustulosis (AGEP) a clinical reaction pattern. J Cutan Pathol 2001;28:113-9.

2. Sidoroff A, Dunant A, Viboud $C$, et al: Risk factors for acute generalized exanthematous pustulosis (AGEP) results of a multinational case-control study (EuroSCAR). Br J Dermatol 2007;157:989-96.

3. Park MY, Kang HY: Acute generalized exanthematous pustulosisafter ingestion of lacquer chicken. Ann Dermato1 2008;20:209-11.

4. Young PC, Turiansky GW, Bonner MW, et al: Acute generalized exanthematous pustulosis induced by chromium picolinate. J Am Acad Dermatol 1999;41:820-3.

5. Belhadjali H, Mandhouj S, Moussa A, et al: Mercury-induced acute generalized exanthematous pustulosis misdiagnosed as adrug-related case. Contact Dermatitis 2008;59:52-4.

6. Davidovici BB, Pavel D, Cagnano E, et al: Acute generalized exanthematous pustulosis following a spider bite: report of 3 cases. J Am Acad Dermatol 2006;55:525-9.

7. Makris M, Spanoudaki N, Giannoula F, et al: Acute generalized exanthematous pustulosis (AGEP) triggered by a spider bite. Allergol Int 2009;58:301-3.

8. Ermertcan AT, Demirer O, Inanir I, et al: Acute generalized exanthematous pustulosis with lymphangitis triggered by a spider bite. Cutan Ocul Toxicol 2010;29:67-9.

9. Lane L, McCoppin HH, Dyer J: Acute generalized exanthematous pustulosis and Coombs-positive hemolytic anemia in a child following Loxosceles reclusa envenomation. Pediatr Dermatol 2011;28:685-8.

10. de Mattos Milman L, Müller GP, Souza PR, et al: Acute generalized exanthematous pustulosis associated with spider bite. An Bras Dermatol 2016;91:524-7.

11. Bhat $Y J$, Hassan I, Sajad $P$, et al: Acute generalized exanthematous pustulosis due to insect bites? Indian J Dermatol 2015;60:422.

12. Pippirs $U$, Mehlhorn $H$, Antal AS, et al: Acute generalizedexanthematous pustulosis following a Loxosceles spider bite in Great Britain. Br J Dermatol 2009;161:208-9.

13. Ben Said Z, Saidi W, Boussofara L, et al: Acute generalized exanthematous pustulosis following a spider bite:three cases from Tunisia. Ann Dermatol Venereol 2010;137:813-8.

14. Valeyrie-Allanore L, Obeid G, Revuz J: Drug reactions. In: Dermatology. Ed. Bolognia JL, Schaffer JV, Jorizzo JL. 4th Edition. China: Elsevier; 2018:358-9. 